\title{
THE ACTION OF COX/LOX INHIBITORS ON ANTIOXIDANT SYSTEM AND MORPHOLOGICAL STATE OF RAT'S COLON MUCOSA UNDER THE CONDITIONS OF STRESS
}

\begin{abstract}
Introduction. Extensive, and often uncontrolled, use of cyclooxygenase (COX) inhibitors, as well as the psychological stress, are important factors of inflammatory diseases development in the digestive tract, including the large intestine. The activation of lipoperoxidation processes is one of the pathogenetic links of the development of ulcers, which can serve as a marker for both the intensity of inflammation and the onset of proinflammatory state.

The aim of the study - to find out the influence of certain COX and lipoxygenase (LOX) inhibitors on the activity of free radical oxidation and the morphological state of the colon mucosa (CM) under the conditions of their independent action and under the conditions of stress.

Research Methods. A model of 5 hours water-immobilization stress was selected for the stress simulation, for inhibition of COX and LOX - naproxen, celecoxib and compound $2 A 5 D H T$, which were administered intragastrically, in a single dose of $10 \mathrm{mg} / \mathrm{kg}$. The morphological study of CM and the determination of the antioxidant enzymes activity in the CM homogenates were conducted.

Results and Discussion. The single action of naproxen caused increase of SOD, catalase, MPO activity and TBA-active products concentration in the CM. Similar changes were noted under the conditions of stress. Administration of naproxen under the conditions of stress caused the increase of SOD activity compared to WIS action and increase of TBA-active products concentration, activity of catalase and MPO compared to naproxen action.

Conclusions. It was found that non-selective COX inhibition was accompanied by proinflammatory effect in the CM, likely based on the prooxidant action of the nonselective COX inhibitor, which was confirmed by the activation of SOD. Selective COX-2 inhibition and inhibition of COX-2/5-LOX showed an anti-inflammatory effect due to a more effective mechanism of action.
\end{abstract}

KEY WORDS: cyclooxygenase; lipoxygenase; stress; antioxidant defense; free radical oxidation; colon.

INTRODUCTION. The COX inhibitors are widely used in medicine as non-steroidal anti-inflammatory drugs (NSAIDs) due to their ability to block the synthesis of proinflammatory prostaglandins (PGs) [1]. As many of them, mainly analgesics, belong to over-the-counter medicines group, it has resulted in the uncontrolled use of NSAIDs [2].

The inhibition of COX results also in the decrease of gastroprotective PGs production, which leads to the insufficient production of mucus and bicarbonates by the digestive tract organs mucosa [3]. Therefore, ulcers development of the digestive tract mucosa is the most common side effect of NSAIDs [4]. The research of safer, but enough effective NSAIDs is an actual question of different sciences related to the medicine [5]. Modern directions of NSAIDs improvement include the synthesis of more selective COX-2 inhibitors [1], dual inhibitors of COX-2 and 5-LOX [6] and incorporation of differ(c) N. V. Denysenko, O. Ya. Sklyarov, 2019. ent radicals with cytoprotective properties into the known molecule structure [7].

The psychological stress is another trigger of inflammatory diseases of the digestive tract development, as stress is accompanied by increased production of catecholamines and cortisol later [8]. The action of adrenaline on the colon mucosa (CM) manifests by vasoconstriction [9] and disturbed motor function [10]. Cortisol and other corticosteroids, like corticoliberin and urocortin, cause ischemia, increased cell membrane permeability, visceral sensitivity [11] on the one hand and inhibit phospholipase $A_{2}$ via lipocortin synthesis induction [12] on the other. Taken together, these mechanisms can activate cell damage, and result in the free radical oxidation activation.

Free radicals (superoxide radical, hydrogen peroxide, hydroxyl radical etc.) are produced by the $\mathrm{CM}$ in response to the action of infectious factors under the normal conditions and provide cell death 
under the pathological states like inflammation, stress, the action of chemical or physical stimuli [13]. Lipids of cell and mitochondrial membranes are the most sensitive molecules to free radical oxidation [14]. The final product of their chemical transformation is malonic dialdehyde, which can bind with thiobarbituric acid (TBA) [15]. The contraction to the lipid peroxidation is provided by the antioxidant enzymes - superoxide dismutase (SOD), catalase, glutathione peroxidase [16] and in some way by myeloperoxidase (MPO), which transforms hydrogen peroxide by neutrophils, and is also a marker of neutrophil infiltration [17].

The aim of the study - to find out the influence of certain COX and LOX inhibitors on the activity of lipid peroxidation and the morphological state of the CM under the conditions of their independent action and under conditions of stress.

RESEARCH METHODS. The experiment was conducted on 80 outbred rats of both sexes with the body weight of $200-240 \mathrm{~g}$. All manipulations with the animals were carried out according to European Convention for the Protection of Vertebrate Animals used for Experimental and Other Scientific Purposes and permitted by Bioethics Committee of Danylo Halytskyi Lviv National Medical University (Protocol No. 3, 16.03.2015). The animals were kept on the standard diet with free access to the water.

The rats were divided into 8 groups: group 1 was a control group (intact), animals of the groups 2,3 and 4 were administered COX inhibitors - nonselective naproxen (group 2), COX-2 selective celecoxib (group 3) and dual COX-2/5-LOX 2A5DHT (group 4). All the COX inhibitors were administered intragastrically at a single dose of $10 \mathrm{mg} / \mathrm{kg}$. The animals of the groups 5-8 were fasting for 24 hours and then were subjected to water-immersion stress (WIS) duration of 5 hours, water temperature was $20-23^{\circ} \mathrm{C}$ [18]. The rats of the groups 6-8 were administered COX inhibitors 1 hour before WIS by the same scheme as animals of groups 2-4. Euthanasia was carried out by the urethan injection at a dose of $4 \mathrm{~g} / \mathrm{kg}$.
The colons were washed with the saline solution, the samples were taken for the histological examination and average goblet cells number in a crypt was measured using ImageJ program. The $\mathrm{CM}$ was removed and the homogenates were prepared in the $0.9 \%$ saline solution (1:5). The activity of SOD [19], catalase [20], MPO [21] and the concentration of TBA-active products [22] was measured in the CM homogenates.

Statistical analysis was performed using program OriginPro 7.0. Data are presented as the mean and standard deviation. The reliability was determined using the Student's test because distribution, determined using the Shapiro-Wilk test, was normal.

RESULTS AND DISCUSSION. The action of COX inhibitors did not cause any morphological changes in the $\mathrm{CM}$. The administration of naproxen caused increase of TBA-active products concentration by $16 \%(p<0.05)$, activity of SOD by $37 \%$ $(p<0.05)$, catalase by $37 \%(p<0.01)$ and MPO by $50 \%(p<0.01)$ compared to the control group (Table 1). Absence of morphological changes and increase in TBA-active products concentration in CM under the action of naproxen was also noted in our previous investigation [23]. There were no significant changes in studied biochemical indices in groups of celecoxib and 2A5DHT compared to control group.

We suppose that the activation of free radical oxidation may be caused by two reasons. First - by special properties of naproxen, which can increase expression of NADPH-oxidase-4 [24] thus causing the increased concentration of superoxide radical and activation of SOD, which turns superoxide into hydrogen peroxide. The increased concentration of hydrogen peroxide leads to the increased activity of catalase and MPO, which are using it as a substrate. The increased concentration of both superoxide radical and hydrogen peroxide activates lipid peroxidation, so it results in increased TBA-active products concentration. Another possible reason is connected with the mechanism of naproxen action - it inhibits the synthesis of protective PGs [4],

Table 1 - The concentration of TBA-active products and activity of SOD, catalase and MPO in $\mathrm{CM}$ under the action of COX-inhibitors ( $\mathrm{M} \pm \mathrm{m})$

\begin{tabular}{|l|c|c|c|c|}
\hline \multicolumn{1}{|c|}{ Group } & $\begin{array}{c}\text { TBA-active } \\
\text { products, } \\
\mu \text { moles/g tissue }\end{array}$ & $\begin{array}{c}\mu \text { SOD, } \\
\text { tetrazolium/min'mg } \\
\text { of protein }\end{array}$ & $\begin{array}{c}\text { Catalase, } \\
\mu \text { moles of } \mathrm{H}_{2} \mathrm{O}_{2} / \\
\text { min·mg of protein }\end{array}$ & $\begin{array}{c}\text { MPO, } \\
\mu \text { moles of } \mathrm{H}_{2} \mathrm{O}_{2} / \\
\text { min·mg of protein }\end{array}$ \\
\hline Control $(\mathrm{n}=10)$ & $0.95 \pm 0.10$ & $7.31 \pm 1.43$ & $15.80 \pm 2.30$ & $0.04 \pm 0.01$ \\
\hline Naproxen $(\mathrm{n}=10)$ & $1.10 \pm 0.05^{*}$ & $9.99 \pm 1.36^{\star}$ & $21.60 \pm 2.65^{\star \star}$ & $0.06 \pm 0.01^{\star \star}$ \\
\hline Celecoxib $(\mathrm{n}=10)$ & $0.95 \pm 0.16$ & $7.47 \pm 1.69$ & $15.50 \pm 2.89$ & $0.05 \pm 0.01$ \\
\hline 2A5DHT $(\mathrm{n}=10)$ & $1.04 \pm 0.17$ & $6.18 \pm 1.25$ & $17.60 \pm 3.27$ & $0.05 \pm 0.01$ \\
\hline
\end{tabular}

Notes. ${ }^{*}-p<0.05$ compared to control group; ${ }^{*}-p<0.01$ compared to control group. 
so $\mathrm{CM}$ is not protected enough from aggressive factors present in the feces.

Combined action of WIS and COX inhibitors did not predetermine any macroscopic changes of $\mathrm{CM}$, but we found out that the CM surface was damaged and there were changes in histological indices. In particular, there were $\mathrm{CM}$ erosions under conditions of WIS, combined action of naproxen and WIS caused increase of erosions, whereas action of celecoxib and 2A5DHT under conditions of WIS contributed to the preservation of $\mathrm{CM}$ integrity (Fig. 1, erosions are marked with arrows). Similar histological changes were noted under the action of WIS and combined action of naproxen and WIS in rat's gastric mucosa [25].

The investigation of histological specimens revealed that under conditions of WIS the average number of goblet cells in crypt decreases by $44 \%$ $(p<0.001)$ compared to control group (Fig. 2). The administration of naproxen and celecoxib under conditions of WIS did not change it reliably compared to WIS group, whereas 2A5DHT caused increase of average goblet cells number by $30 \%$ $(p<0.05)$ compared to WIS group. Goblet cells are producing and accumulate mucus, so the increase or decrease of their number reflects the level of the $\mathrm{CM}$ protection. These data indicate that 2A5DHT has more effective anti-inflammatory effect and is less ulcerogenic due to its mechanism of action, which provides synthesis of protective PGs and inhibit production of both inflammatory PGs and leucotriens.

The action of WIS caused increase in TBAactive products concentration by $57 \%(p<0.001)$, activity of SOD by $44 \%(p<0.001)$, catalase - by $43 \%(p<0.001)$, MPO - by $325 \%(p<0.001)$ compared to control group (Table 2). We received increased concentration of TBA-active products in the CM [26] and MPO activity in gastric mucosa [25] and under conditions of WIS previously. Activation of the antioxidant enzymes is a marker of free radicals accumulation, which is possibly connected with ischemia, developed under the action of adrenaline. The administration of naproxen under

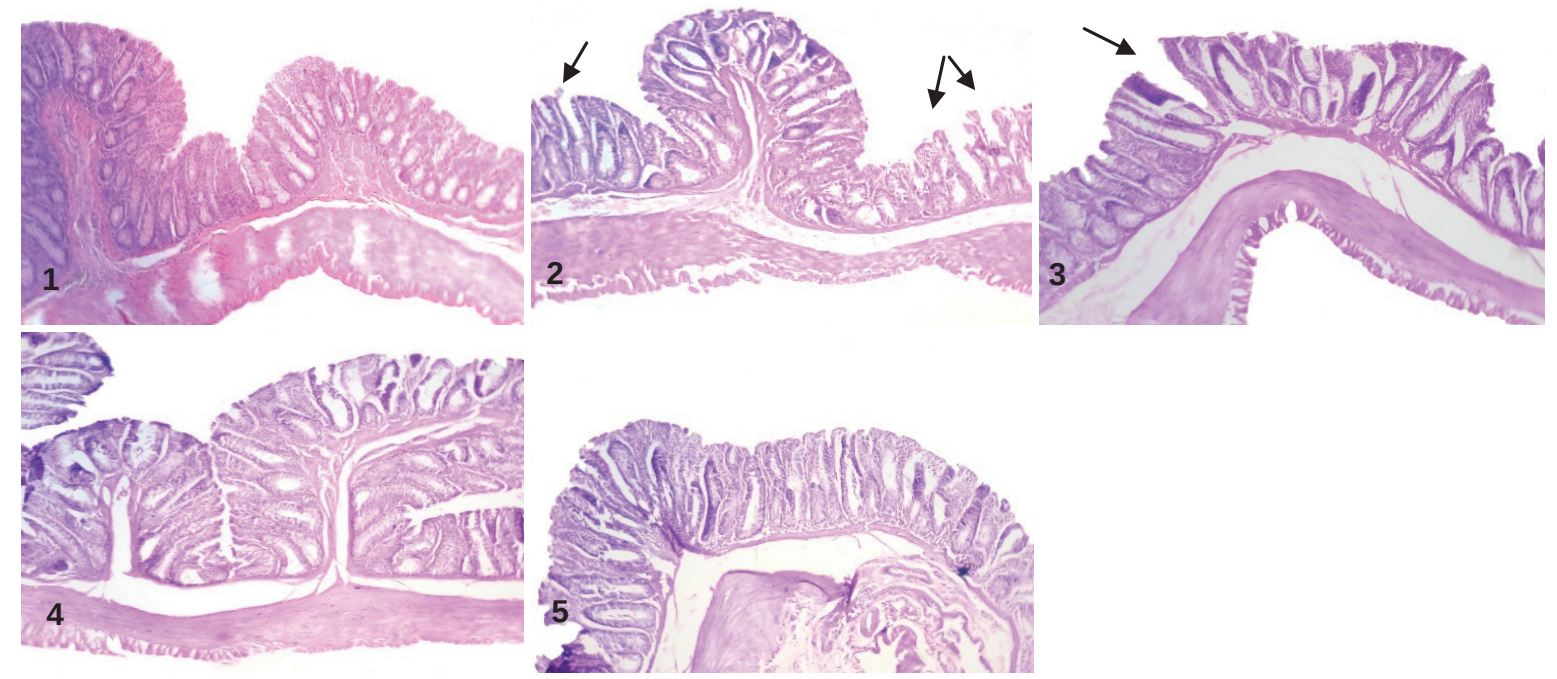

Fig. 1. Colon histology, hematoxylin-eosin stained, $\times 100$ magnification.

Notes. 1 - control group; 2 - WIS group; 3 - WIS + naproxen group; 4 - WIS + celecoxib group; 5-WIS + 2A5DHT group.

Table 2 - The concentration of TBA-active products and activity of SOD, catalase and MPO in $\mathrm{CM}$ under the combined action of WIS and COX-inhibitors (M $\pm m)$

\begin{tabular}{||l|c|c|c|c||}
\hline \multicolumn{1}{|c|}{ Groups } & $\begin{array}{c}\text { TBA-active } \\
\text { products, } \mu \text { moles/g } \\
\text { tissue }\end{array}$ & $\begin{array}{c}\text { SOD, } \\
\mu \text { moles of nitroblue } \\
\text { tetrazolium/min·mg } \\
\text { of protein }\end{array}$ & $\begin{array}{c}\text { Catalase, } \\
\mu \text { moles of } \mathrm{H}_{2} \mathrm{O}_{2} / \\
\text { min·mg of protein }\end{array}$ & $\begin{array}{c}\text { MPO, } \\
\mu \text { moles of } \mathrm{H}_{2} \mathrm{O}_{2} / \\
\text { min·mg of protein }\end{array}$ \\
\hline Control $(\mathrm{n}=10)$ & $0.95 \pm 0,10$ & $7.31 \pm 1.43$ & $15.80 \pm 2.30$ & $0.04 \pm 0.01$ \\
\hline WIS $(\mathrm{n}=10)$ & $1.49 \pm 0.19^{\star \star \star}$ & $10.50 \pm 1.37^{\star \star \star}$ & $22.60 \pm 2.71^{\star \star \star}$ & $0.13 \pm 0.02^{\star \star \star}$ \\
\hline WIS+naproxen $(\mathrm{n}=10)$ & $1.36 \pm 0.15^{\wedge \wedge}$ & $13.40 \pm 1.54^{\#}$ & $26.10 \pm 2.67^{\wedge \wedge}$ & $0.15 \pm 0.03^{\wedge \wedge \wedge}$ \\
\hline WIS+celecoxib $(\mathrm{n}=10)$ & $1.39 \pm 0.13$ & $11.00 \pm 1.60$ & $23.50 \pm 2.44$ & $0.14 \pm 0.03$ \\
\hline WIS+2A5DHT $(\mathrm{n}=10)$ & $1.39 \pm 0.18$ & $9.77 \pm 1.11$ & $22.00 \pm 2.11$ & $0.12 \pm 0.03$ \\
\hline
\end{tabular}

Notes:

1. *** $-p<0.001$ compared to control group.

2. ${ }^{*}-\mathrm{p}<0.05$ compared to WIS group.

3. ${ }^{\wedge}-p<0.01$ compared to naproxen group.

4. ${ }^{\wedge \wedge}-p<0.001$ compared to naproxen group. 


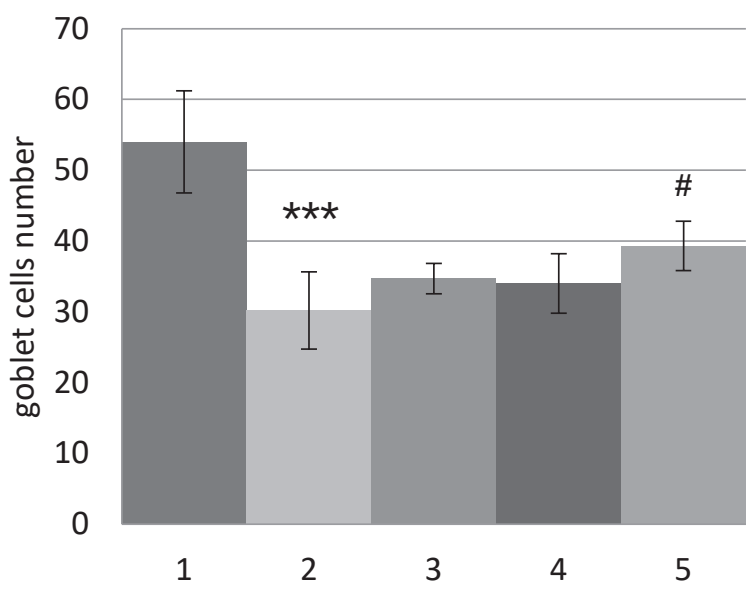

Fig. 2. The average number of goblet cells in crypt.

Notes. 1 - control group; 2 -WIS group; 3 -WIS + naproxen group; $4-$ WIS + celecoxib group; $5-$ WIS + 2A5DHT group; ${ }^{* \star}-p<0.001$ compared to control group; ${ }^{*}-p<0.05$ compared to WIS group.

the conditions of WIS promoted increase of SOD activity by $28 \%(p<0.05)$ compared to WIS group; increase of TBA-active products concentration by $24 \%(p<0.01)$, activity of catalase by $21 \%(p<0.01)$, MPO - by $250 \%(p<0.001)$ compared to naproxen group (Table 2). We did not note increase of TBAactive products in any of groups compared to WIS group, the same results we received in previous experiment, but there was the decrease of TBAactive products compared to WIS group in gastric mucosa [26]. Probably, upper gastro-intestinal tract

\section{LIST OF LITERATURE}

1. Selective cyclooxygenase inhibitors: current status / N. Ravindran, R. Y. Prasanna, R. K. Yengala, R. Malepati // Current Drug Discovery Technologies. 2014. - No. 11. - P. 127-132.

2. High-risk use of over-the-counter non-steroidal anti-inflammatory drugs: A population-based cross-sectional study / A. R. Koffeman, V. E. Valkhoff, S. Çelik [et al.] // British Journal of General Practice. - 2014. No. 621. - P. E191-E198.

3. Takeuchi K. Roles of cyclooxygenase, prostaglandin $E_{2}$ and EP receptors in mucosal protection and ulcer healing in the gastrointestinal tract / K. Takeuchi, K. Amagase // Current Pharmaceutical Design. - 2018. No. 24. - P. 2002-2011.

4. Scheiman J. M. NSAID-induced gastrointestinal injury / J. M. Scheiman // Journal of Clinical Gastroenterology. - 2016. - No. 50. - P. 5-10.

5. Leopold S. S. Editorial: when "safe and effective" becomes dangerous / S. S. Leopold // Clinical Orthopaedics and Related Research. -2014. - No. 472. - P. 19992001.

6. Novel di-tertiary-butyl phenylhydrazones as dual cyclooxygenase-2/5-lipoxygenase inhibitors: Synthesis, is more sensitive to WIS and NSAIDs action compared to colon. Interestingly, that increase of SOD and catalase activity under the action of naproxen is almost the same as under the WIS action. These data indicate the prooxidative action of naproxen, which increases under conditions of stress and probably is connected with NADPH-oxidase expression activation [24]. Another mechanism may be connected with protective PGs synthesis inhibition by both naproxen via COX-1 [3] and cortisol via lipocortin [12], so it results in decrease of mucosal layer protective function. Administration of celecoxib and 2A5DHT did not cause reliable pro- or antioxidant action on $\mathrm{CM}$ under the conditions of WIS, which confirms that WIS action is more determinative.

CONCLUSIONS. 1. Non-selective COX inhibitor (naproxen) has a prooxidant and proinflammatory action on colon mucosa, which is very similar to the action of stress and manifested by increase of TBA-active products concentration and activity of SOD, catalase, MPO.

2. Combined action of stress and non-selective COX inhibitor ameliorates free radical oxidation, which was proved by SOD activation.

3. Selective COX-2 and dual COX-2/5-LOX inhibitors (celecoxib and 2A5DHT) did not promote proinflammatory or prooxidant action on colon mucosa neither under conditions of their action alone, nor under the conditions of stress.

COX/LOX inhibition, molecular modeling, and insights into their cytotoxicities / S. Ghatak, A. Vyas, S. Misra [et al.] // Bioorganic \& Medicinal Chemistry Letters. 2014. - No. 24. - P. 317-324.

7. Wallace J. L. Gaseous mediators in gastrointestinal mucosal defense and injury / J. L. Wallace, A. Ianaro, G. de Nucci. // Digestive Diseases and Sciences. 2017. - No. 62. - P. 2223-2230.

8. Stress and the microbiota-gut-brain axis in visceral pain: relevance to irritable bowel syndrome / R. D. Moloney, A. C. Johnson, S. M. O'Mahony [et al.] // CNS Neuroscience \& Therapeutics. - 2015. - No. 22. P. 102-117.

9. Norepinephrine increases calcium sensitivity of mouse afferent arteriole, thereby enhancing angiotensin II-mediated vasoconstriction / E. Y. Lai, M. Fähling, Z. Ma [et al.] // Kidney International. - 2009. - No. 76. - P. 953959.

10. Lomax A. E. The participation of the sympathetic innervation of the gastrointestinal tract in disease states / A. E. Lomax, K. A. Sharkey, J. B. Furness. // Neurogastroenterology \& Motility. - 2009. - No. 22. P. 7-18. 
11. Taché Y. Role of corticotropin-releasing factor signaling in stress-related alterations of colonic motility and hyperalgesia / Y. Taché, M. Million // Journal of Neurogastroenterology and Motility. - 2015. - No. 21. P. 8-24.

12. Samuel S. Pharmacologic characteristics of corticosteroids / S. Samuel, T. Nguyen, A. Choi // Journal of Neurocritical Care. - 2017. - No. 10. - P. 53-59.

13. Antioxidant effects of gastrointestinal digested purple carrot extract on the human cells of colonic mucosa / A. Olejnik, J. Rychlik, M. Kidon [et al.] // Food Chemistry. - 2016. - No. 190. - P. 1069-1077.

14. Sisein E. A. Biochemistry of free radicals and antioxidants / Sisein. // Scholars Academic Journal of Biosciences. - 2014. - No. 2. - P. 110-118.

15. Morozov A. A. Responses of hepatic biochemical markers in bream Abramis brama L. to dietary administered polychlorinated biphenyls / A. A. Morozov, V. V. Yurchenko // Contemporary Problems of Ecology. - 2016. No. 9. - P. 78-85.

16. Yang H. Y. Antioxidant enzymes as redox-based biomarkers: a brief review / H. Y. Yang, T. H. Lee // BMB Reports. - 2015. - No. 48. - P. 200-208.

17. Evaluation of oxidative stress and antioxidant status: Correlation with the severity of sepsis [Electronic resource] / S. Kumar, E. Gupta, S. Kaushik [et al.] // Scandinavian Journal of Immunology. - 2018. - Access mode : https://www.ncbi.nlm.nih.gov/pubmed/29484685.

18. Takagi K. Studies on the drugs for peptic ulcer A reliable method for producing stress ulcer in rats K. Takagi, Y. Kasuya, K. Watanabe // Chemical and Pharmaceutical Bulletin. - 1964. - No. 12. - P. 465-472.

19. Горячковский А. М. Клиническая биохимия / А. М. Горячковский. - Одесса, 1998. - С. 368-369.

20. Метод определения активности каталазы / [М. А. Королюк, Л. И. Иванова, И. Г. Майорова и др.] // Лаб. дело. - 1988. - № 1. - С. 16-19.

\section{REFERENCES}

1. Ravindran, N., Prasanna, R.Y., Yengala, R.K., \& Malepati, R. (2014). Selective cyclooxygenase inhibitors: current status. Current Drug Discovery Technologies, 11 (2), 127-132.

2. Koffeman, A.R., Valkhoff, V.E., Çelik, S., Jong, G.W., Sturkenboom, M.C., Bindels, P. J., . . . Bierma-Zeinstra, S.M. (2014). High-risk use of over-the-counter nonsteroidal anti-inflammatory drugs: A population-based cross-sectional study. British Journal of General Practice, 621(64), E191-E198.

3. Takeuchi, K., \& Amagase, K. (2018). Roles of cyclooxygenase, prostaglandin $\mathrm{E}_{2}$ and EP receptors in mucosal protection and ulcer healing in the gastrointestinal tract. Current Pharmaceutical Design, 24 (18), 2002 2011.

4. Scheiman, J.M. (2016). NSAID-induced gastrointestinal injury. Journal of Clinical Gastroenterology, 50(1), 5-10.

5. Leopold, S. S. (2014). Editorial: when "safe and effective" becomes dangerous. Clinical Orthopaedics and Related Research, 472 (7), 1999-2001.

6. Ghatak, S., Vyas, A., Misra, S., O'Brien, P., Zambre, A., Fresco, V.M., . . . Padhye, S. (2014). Novel
21. Bradley P. P. Cellular and extracellular myeloperoxidase in pyogenic inflammation / P. P. Bradley, R. D. Christensen, G. Rothstein // Blood. - 1982. No. 60. - P. 618-622.

22. Тимирбулатов М. А. Метод повышения интенсивности свободнорадикального окисления липидосодержащих компонентов крови и его диагностическое значение / М. А. Тимирбулатов, Е. И. Селезнев // Лаб. дело. - 1981. - № 4. - С. 209-211.

23. $\mathrm{H}_{2} \mathrm{~S}-3 \mathrm{~B}$ 'язаний нестероїдний протизапальний засіб АТВ-346 володіє зниженою гастротоксичністю порівняно з впливом його структурного аналога напроксену / Н. В. Денисенко, І. С. Фоменко, Ю. М. Федевич, О. Я. Скляров // Мед. хімія. - 2014. - 16, № 4 (61). - C. 26-29.

24. Non-steroidal anti-inflammatory drugs activate $\mathrm{NADPH}$ oxidase in adipocytes and raise the $\mathrm{H}_{2} \mathrm{O}_{2}$ pool to prevent CAMP-stimulated protein kinase a activation and inhibit lipolysis [Electronic resource] / H. VázquezMeza, M. Z. de Piña, J. P. Pardo [et al.] // BMC Biochemistry. - 2013. -Access mode: https://www.ncbi.nlm. nih.gov/pubmed/23718778.

25. Interactions between nitric oxide and hydrogen sulfide generating systems in gastric mucosa under condition of the combined action of stress and NDAIDs / I. Fomenko, A. Sklyarov, N. Denysenko [et al.] // Journal of Applied Pharmaceutical Science. - 2017. - No. 7. P. 013-019.

26. Changes of nitric oxide system and lipid peroxidation parameters in the digestive system of rats under conditions of acute stress, and use of nonsteroidal antiinflammatory drugs / I. Fomenko, T. Bondarchuk, V. Emelyanenko [et al.] // Current Issues in Pharmacy and Medical Sciences. - 2015. - No. 28. - P. 37-41.

di-tertiary-butyl phenylhydrazones as dual cyclooxygenase-2/5-lipoxygenase inhibitors: Synthesis, COX/LOX inhibition, molecular modeling, and insights into their cytotoxicities. Bioorganic \& Medicinal Chemistry Letters, 24 (1), 317-324.

7. Wallace, J. L., Ianaro, A., \& de Nucci, G. (2017). Gaseous mediators in gastrointestinal mucosal defense and injury. Digestive Diseases and Sciences, 62 (9), 2223-2230.

8. Moloney, R.D., Johnson, A. C., O'Mahony, S.M., Dinan, T.G., Greenwood-Van Meerveld, B., \& Cryan, J.F. (2015). Stress and the microbiota-gut-brain axis in visceral pain: relevance to irritable bowel syndrome. CNS Neuroscience \& Therapeutics, 22 (2), 102-117.

9. Lai, E.Y., Fähling, M., Ma, Z., Källskog, O., Persson, P.B., Patzak, A., ... Hultström, M. (2009). Norepinephrine increases calcium sensitivity of mouse afferent arteriole, thereby enhancing angiotensin II-mediated vasoconstriction. Kidney International, 76 (9), 953-959.

10. Lomax, A.E., Sharkey, K.A., \& Furness, J.B. (2009). The participation of the sympathetic innervation of the gastrointestinal tract in disease states. Neurogastroenterology \& Motility, 22 (1), 7-18. 
11. Taché, Y., \& Million, M. (2015). Role of corticotropin-releasing factor signaling in stress-related alterations of colonic motility and hyperalgesia. Journal of Neurogastroenterology and Motility, 21 (1), 8-24.

12. Samuel, S., Nguyen, T., \& Choi, A. (2017). Pharmacologic characteristics of corticosteroids. Journal of Neurocritical Care, 10 (2), 53-59.

13. Olejnik, A., Rychlik, J., Kidon, M., Czapski, J., Kowalska, K., Juzwa, W., ... Pat Moyer, M. (2016). Antioxidant effects of gastrointestinal digested purple carrot extract on the human cells of colonic mucosa. Food Chemistry, 190, 1069-1077.

14. Sisein, E.A. (2014). Biochemistry of free radicals and antioxidants. Scholars Academic Journal of Biosciences, 2 (2), 110-118.

15. Morozov, A.A., \& Yurchenko, V.V. (2016). Responses of hepatic biochemical markers in bream Abramis brama L. to dietary administered polychlorinated biphenyls. Contemporary Problems of Ecology, 9 (1), 78-85.

16. Yang, H.-Y., \& Lee, T.-H. (2015). Antioxidant enzymes as redox-based biomarkers: a brief review. $B M B$ Reports, 48 (4), 200-208.

17. Kumar, S., Gupta, E., Kaushik, S., Kumar Srivastava, V., Mehta, S., \& Jyoti, A. (2018). Evaluation of oxidative stress and antioxidant status: Correlation with the severity of sepsis. Scandinavian Journal of Immunology, 87 (4), e12653.

18. Takagi, K., Kasuya, Y., \& Watanabe, K. (1964). Studies on the drugs for peptic ulcer. A reliable method for producing stress ulcer in rats. Chemical and Pharmaceutical Bulletin, 12 (4), 465-472.

19. Goryachkovskyy, A.M. (1998). Klinicheskaya Biokhimiya [Clinical Biochemistry]. Odessa [in Russian].

20. Korolyuk, M.A., Ivanova, L.I., \& Mayorova, I.G. (1988). Metod opredeleniya aktivnosti katalazy [The method of catalase activity determination]. Laboratornoye Delo - Laboratory Work, 1, 16-19 [in Russian].
21. Bradley, P.P., Christensen, R.D., \& Rothstein, G. (1982). Cellular and extracellular myeloperoxidase in pyogenic inflammation. Blood, 60, 618-622.

22. Timirbulatov, M.A., \& Syelyeznyov, Ye.I. (1981). Metod povysheniya intensivnosti svobodnoradicalnogo okisleniya lipidosoderzhashchikh komponentov krovi i yego diagnosticheskoye znacheniye [The method of increase of intensity of free-radical oxidation of lipid-containing in blood and its diagnostic signisficance]. Laboratornoye Dyelo - Laboratory Work, 4, 209-211 [in Russian].

23. Denysenko, N.V., Fomenko, I.S., Fedevych, Yu.M., \& Skliarov, O.Ya. (2014). HS-zviazanyi nesteroyidnyi protyzapalnyi preparat ATB-346 volodiie znyzhenoiu hastrotoksychnistiu porivniano z vplyvom yoho strukturnoho analoha naproksenu $\left[\mathrm{H}_{2} \mathrm{~S}\right.$-releasing non-steroidal anti-inflammatory drug ATB-346 has lower gastrotoxicity compared with structure analogue naproxen]. Medychna khimiia - Medical Chemistry, 16 (4), 26-29 [in Ukrainian].

24. Vázquez-Meza, H., de Piña, M.Z., Pardo, J.P., Riveros-Rosas, H., Villalobos-Molina, R., \& Piña, E. (2013). Non-steroidal anti-inflammatory drugs activate NADPH oxidase in adipocytes and raise the $\mathrm{H}_{2} \mathrm{O}_{2}$ pool to prevent cAMP-stimulated protein kinase a activation and inhibit lipolysis. BMC Biochemistry, 14 (1). Retrieved from: https://doi.org/10.1186/1471-2091-14-13

25. Fomenko, I., Sklyarov, A., Denysenko, N., Hrycevych, N., Dranitsyna, A., \& Wallace, J. (2017). Interactions between nitric oxide and hydrogen sulfide generating systems in gastric mucosa under condition of the combined action of stress and NDAIDs. Journal of Applied Pharmaceutical Science, 7 (08), 013-019.

26. Fomenko, I., Bondarchuk, T., Emelyanenko, V., Denysenko, N., Sklyarov, P., Ilkiv, I., ... Sklyarov, A. (2015). Changes of nitric oxide system and lipid peroxidation parameters in the digestive system of rats under conditions of acute stress, and use of nonsteroidal antiinflammatory drugs. Current Issues in Pharmacy and Medical Sciences, 28 (1), 37-41.

Н. В. Денисенко, О. Я. Скляров ЛЬВІВСЬКИЙ НАЦІОНАЛЬНИЙ МЕДИЧНИЙ УНІВЕРСИТЕТ ІМЕНІ ДАНИЛА ГАЛИЦЬКОГО

\section{ВПЛИВ ІНГІБІТОРІВ ЦИКЛООКСИГЕНАЗИ/ЛІПООКСИГЕНАЗИ НА АНТИОКСИДАНТНУ СИСТЕМУ ТА МОРФОЛОГІЧНИЙ СТАН СЛИЗОВОЇ ОБОЛОНКИ ТОВСТОЇ КИШКИ ЩУРІВ ЗА УМОВ СТРЕСУ}

\section{Резюме}

Вступ. Широке і часто неконтрольоване застосування інгібіторів циклооксигенази, а також психологічний стрес - важливі фрактори виникнення хронічних запальних захворювань органів травлення, в тому числі й у товстій кишці. Однією з патогенетичних ланок утворення виразок $є$ активація процесів ліпопероксидації, що може слугувати маркером як інтенсивності запалення, так і виникнення прозапального стану.

Мета дослідження - з'ясувати вплив деяких інгібіторів циклооксигенази та ліпооксигенази на активність вільнорадикального окиснення і морфологічний стан слизової оболонки товстої кишки за умов самостійної дії та на тлі стресу.

Методи дослідження. Для моделювання стресу було обрано модель водно-іммобілізаційного стресу тривалістю 5 год з метою інгібування циклооксигенази та ліпооксигенази - напроксен, целекоксиб і спо- 
луку 2A5DHT, які вводили внутрішньошлунково одноразово в дозі 10 мг/ке. Виконували морфологічне дослідження слизової оболонки товстої кишки і визначали активність ензимів антиоксидантного захисту в гомогенатах слизової оболонки товстої кишки.

Результати й обговорення. Самостійна дія напроксену зумовила зростання активності супероксиддисмутази, каталази, мієлопероксидази та концентрації ТБК-активних продуктів у слизовій оболонці товстої кишки. Схожі зміни було відзначено за умов водно-іммобілізаційного стресу. Введення напроксену на тлі водно-іммобілізаційного стресу спричинило підвищення активності супероксиддисмутази порівняно з дією цього стресу, збільшення вмісту ТБК-активних продуктів, зростання активності каталази $і$ мієлопероксидази порівняно з дією напроксену.

Висновки. Встановлено, що неселективне інгібування циклооксигенази супроводжується прозапальним впливом на слизову оболонку товстої кишки, в основі якого, ймовірно, лежить прооксидантна дія неселективного інгібітора циклооксигенази, що підтверджується активацією супероксиддисмутази. Селективне інгібування циклооксигенази-2 та інгібування циклооксигенази-2 і5-ліпооксигенази проявляють протизапальну дію за рахунок більш ефективного механізму дії.

КЛЮЧОВІ СЛОВА: циклооксигеназа; ліпооксигеназа; стрес; антиоксидантний захист; вільнорадикальне окиснення; товста кишка.

Н. В. Денисенко, А. Я. Скляров

ЛЬВОВСКИЙ НАЦИОНАЛЬНЫЙ МЕДИЦИНСКИЙ УНИВЕРСИТЕТ ИМЕНИ ДАНИЛА ГАЛИЦКОГО

\section{ВЛИЯНИЕ ИНГИБИТОРОВ ЦИКЛООКСИГЕНАЗЫ/ЛИПООКСИГЕНАЗЫ НА АНТИОКСИДАНТНУЮ СИСТЕМУ И МОРФОЛОГИЧЕСКОЕ СОСТОЯНИЕ СЛИЗИСТОЙ ОБОЛОЧКИ ТОЛСТОЙ КИШКИ КРЫС В УСЛОВИЯХ СТРЕССА}

\section{Резюме}

Вступление. Широкое и часто неконтролируемое применение ингибиторов циклооксигеназы, а также психологический стресс - важные фракторы возникновения хронических воспалительных болезней органов пищеварения, в том числе и в толстой кишке. Одним из патогенетических звеньев образования язв является активация процессов липопероксидации, что может служить маркером как интенсивности воспаления, так и возникновения провоспалительного состояния.

Цель исследования - определить влияние некоторых ингибиторов циклооксигеназы и липооксигеназы на активность свободнорадикального окисления и морфологическое состояние слизистой оболочки толстой кишки в условиях самостоятельного действия и на фроне стресса.

Методы исследования. Для моделирования стресса было выбрано модель водно-иммобилизационного стресса продолжительностью 5 ч с целью ингибирования циклооксигеназы и липооксигеназы - напроксен, целекоксиб и соединение 2A5DHT, которые вводили внутрижелудочно однократно в дозе 10 мг/ка. Выполняли морфрологическое исследование слизистой оболочки толстой кишки и определяли активность энзимов антиоксидантной защиты в гомогенатах слизистой оболочки толстой кишки.

Результаты и обсуждение. Самостоятельное действие напроксена обусловило возрастание активности супероксиддисмутазы, каталазы, миелопероксидазы и концентрации ТБК-активных продуктов в слизистой оболочке толстой кишки. Похожие изменения были отмечены в условиях водно-иммобилизационного стресса. Введение напроксена на фроне водно-иммобилизационного стресса вызвало повышение активности супероксиддисмутазы в сравнении с этим стрессом, увеличение содержания ТБК-активных продуктов, возрастание активности каталазы и миелопероксидазы в сравнении с действием напроксена.

Выводы. Установлено, что неселективное ингибирование циклооксигеназы сопровождается провоспалительным влиянием на слизистую оболочку толстой кишки, в основе которого, вероятно, лежит прооксидантное действие неселективного ингибитора циклооксигеназы, подтверждающееся активацией супероксиддисмутазы. Селективное ингибирование циклооксигеназы-2 и ингибирование циклооксигеназы-2 и 5-липооксигеназы проявляют противовоспалительное действие за счет более эфроективного механизма действия.

КЛЮЧЕВЫЕ СЛОВА: циклооксигеназа; липооксигеназа; стресс; антиоксидантная защита; свободнорадикальное окисление; толстая кишка.

Received 18.04.19

Address for correspondence: N. V. Denysenko, Danylo Halytskyi Lviv National Medical University, Pekarska street, 69, Lviv, 79010, e-mail: denysenko.natalka@gmail.com. 